University of St. Thomas, Minnesota

UST Research Online

2004

Use of Groups in School Social Work: Group work and group processes

Kendra J. Garrett

University of St. Thomas, Minnesota, KJGARRETT@stthomas.edu

Follow this and additional works at: https://ir.stthomas.edu/ssw_pub

Part of the Clinical and Medical Social Work Commons, Social Work Commons, and the Student

Counseling and Personnel Services Commons

This Article is brought to you for free and open access by the School of Social Work at UST Research Online. It has been accepted for inclusion in Social Work Faculty/Staff Publications by an authorized administrator of UST

Research Online. For more information, please contact asle4660@stthomas.edu. 


\title{
Use of Groups in School Social Work: \\ Group Work and Group Processes
}

\section{Kendra J. Garrett, Ph.D.}

\begin{abstract}
A survey of 54 school social workers indicated that they use group work extensively in their practice to address a number of student issues. Cognitivebehavioral theories were most commonly used to guide these groups, and workers rarely identified the use of small group theory as a conceptual framework. Groups were less frequent at the secondary level, and sessions were longer. Family change groups were more common at the elementary level. The method of funding the social work position had no affect on kinds or numbers of groups school social workers facilitated. Respondents did not identify use of small group theory as a conceptual framework, but they addressed group dynamics and group developmental stages. They used activities extensively and adapted published curriculum to meet member needs.
\end{abstract}




\section{Use of Groups in School Social Work: Group Work and Group Processes}

In addition to being a good use of school social workers' time, groups offer many advantages over work with individual students. When members give and receive support and help from each other, this mutual aid empowers students to feel useful while learning to accept help and support from others. Cohesiveness, the group bond, gives members a sense of belonging and identity as a group member. Groups offer members a number of potential peer relationships beyond the relationship with the worker. Members can learn that they are not alone in dealing with problems (universalization), and they can gain hope through observing others resolve their concerns. Groups offer members a place where they can learn new knowledge and practice new behaviors and skills. Groups provide a place where members can express emotions, thoughts, and ideas. Groups offer members feedback that is often more effective coming from peers than from a social worker (Northern \& Kurland, 2001). There are behavioral (Rose \& Edleson, 1987) and cognitive (LeCroy, 2002) group work practice models that social workers can individualize to meet the needs of their students, using creative activities such as worksheets, toys, games, and published curriculum.

In an attempt to discover the nature and scope of group work practice in schools and to describe the use of small group theory, group activities, and 
published curricula, a survey was mailed to school social workers asking them to describe their group work practices. It was hypothesized that there would be substantial differences between group work practices at the elementary and secondary levels and that funding source for the social work position would have an impact on the kinds of groups social workers conduct. It was further hypothesized that school social workers are using principles of small group theory to develop their groups, even when group principles are not included in curriculum they are using to guide their groups. This article reports the results of that survey and describes the problems that social workers are addressing, the methods they employ, and the theoretical frameworks that guide their groups.

\section{Background of the Study}

Group work activities are used to have fun, to foster creativity, to assess members, to aid communication through non-verbal means, to develop interpersonal relationships, to foster helping, to build competence and confidence, to improve decision making, to change the environment of the group (Northern \& Kurland, 2001), and to help isolated, withdrawn, or silent members interact with others. While some members are more comfortable participating in activities than they are talking with each other, activities can also facilitate discussion (Middleman \& Wood, 1990). Such activities as role-play, cooking, art, singing, puppets, rehearsal of new behaviors, story telling, writing, photography, drama, and athletics have traditionally been used in social work groups. These 
activities are not limited to young children and may be used in groups for any age, so long as the activities fit with member abilities and group purposes (Northern \& Kurland, 2001).

In planning group activities, school social workers can turn to many existing curricula to address such student issues as social skills (Dygdon, 1993; Goldsein \& McGinnis, 1997; McGinnis, Goldstein, Sprafkin, \& Gershaw, 1984; Martin, 1994; Taylor, 1997; Webster-Stratton, Reid, \& Hammond, 2001; Forgan \& Jones, 2002), problem solving (Browning \& Nave, 1993; Nichols, 1997), decision making (Rockwell, 1993; Sunburst, 2000), anger management (Eggert, 1994; Larson, 1992; Lochman, Dunn, \& Klimes-Dougan, 1993), violence prevention (Committee for Children, 1990; Frey \& Sylvester, 1997; Hanna \& Maddalena, 1994), bullying (Beane, 1999; Garrity, Jens, Porter, Sager, \& Short-Camilli, 2000; Sullivan, 2000), and making appropriate choices (Becker \& Barth, 2000). Many of these programs have been empirically validated as successful in resolving social and emotional issues that arise in school settings.

But to be truly effective, group activities, whether created by the worker or adopted from a published curriculum, must not be viewed as the only intervention in group work. Activities should be tied with member understanding about the activity and its place in meeting goals and accomplishing group purpose. Planning should also take group processes into consideration, as group process has a powerful therapeutic effect over and above content of a session (Northern \& Kurland, 2001). Group processes are those interpersonal interactions ongoing 
in the group at any given time. The facilitator monitors such dynamics as group purpose; member and group goals; behaviors; emotional expression; group culture in the form of values, roles, and norms; communication patterns; and interpersonal conflicts (Gavin, 1985; Northern \& Kurland, 2001; Toseland \& Rivas, 2001). As the group develops, the facilitator helps support positive member interactions and develops a positive, cohesive group.

Group activities must also fit with the group's stage of development. After an important pre-group planning phase (Kurland \& Salmon, 1978) members come together in a beginning phase, characterized by members' tentativeness, ambivalence, low commitment to the group, and superficial discussion. This phase sets the stage for future growth by clarifying the purpose of the group and helping members to identify personal goals to address in the group (Garland, Jones, \& Kolodny; 1965). In these early sessions of a group, activities should help members get to know each other, ease tension, and discover similarities (Northern \& Kurland, 2001). There may be some time of conflict in which members attempt to define their roles and status within the group (Garland, Jones, \& Kolodny; 1965). In times of conflict, activities allow members opportunities to work through conflict and compete with each other (Northern \& Kurland, 2001). The middle phase of a group is characterized by cohesion of members who are able to work together towards the purposes of the group and towards attaining personal goals of the members (Garland et al., 1965). In the working phase, activities may include greater cooperation and self-disclosure 
than in other times (Northern \& Kurland, 2001). In groups with female membership, conflict is less likely to happen in early stages of development and tends to occur after relationships have been well established, when members challenge each other constructively to grow and change (Schiller, 1995). The final stage in the life of a group is separation or termination, in which members solidify gains made and work to transfer these gains to situations outside the group (Mayadas \& Glasser, 1981). As the group approaches termination, activities help members to cope with feelings about ending the group and provide an opportunity to reminisce and evaluate the group (Northern \& Kurland, 2001).

Many articles on group work with children describe not only activities to be used in groups but also the interactions, processes, mutual aid, or stages of group development that go together to help students benefit from the intervention (Collins, 1998; DeMar, 1997; Fatout, 1995: Malekoff \& Laser, 1999; Moroz, 1996; Pawlak, Wozniak, \& McGowen, 2002; Mayerson, 2000; Springer, Lynch, \& Rubin, 2000; Witte \& deRidder, 1999; Wohl, 2000). Other children's group descriptions are less clear about the inclusion of group processes in the interventions (Bacha, Pomeroy, \& Gilbert, 1999; LeCroy, 2002; McGinnis et al., 1984; O'Neal, 1997; Woody, 2001). Educational curricula that include a series of lessons to address a particular topic do not always incorporate group process into the lessons. It is possible that group leaders naturally facilitate the development of interpersonal interactions, mutual aid, cohesion, goals, and norms and coordinate activities to fit the stages of group development. On the 
other hand, it is possible that school social workers are doing "casework in a group," in which the leader works individually with members while others watch, thus failing to foster interdependence and mutual aid (Kurland \& Salmon, 1992). But the small group theories cited above clearly recommend that attendance to group dynamics is integral to the helping process.

\section{Methodology}

In an effort to identify and describe the group work practices of school social workers, surveys were mailed to a random sample of 313 members of the School Social Worker's Association of America in the summer of 2002. The 7 page survey was a mixed-use design that included 8 qualitative and 53 quantitative questions asking about respondents' school-based group work practice. Quantitative questions asked about kinds, scope, nature, structure, leadership style, theoretical frameworks, use and adaptation of group curricula, incorporation of group processes and stages of development of the groups they had conducted during the previous school year, and demographics. The qualitative questions were open ended and asked respondents to describe a typical group session, activities used at the various stages of group development, ways they encourage members to be kind and helpful to each other, and favorite resources, programs, or tools. The main purpose of the study was to identify kinds of group work services school social workers are providing and to describe their group work practice, particularly as related to the use of activities, 
developed curricula, and small group processes. There were two independent variables, funding source and grade level, in an attempt to determine if there were differences in the practice of group work with different age levels or when funding sources for school social work services differed.

\section{Sample}

Sixty-seven surveys were returned but of these, 13 respondents indicated that they were in supervisory positions and had not practiced during the previous school year, so their responses were not tallied. There were 54 surveys completed by social workers who were in direct practice in a school setting, for a usable response rate of $17 \%$. The response rate was low, perhaps because some of the addresses were school addresses, and the surveys were mailed during the summer.

The vast majority (94.4\%) of respondents had MSW degrees, $1.9 \%$ had a BSW degree and 3.7\% had doctoral level degrees. They were an experienced group, averaging 13.11 years practice $(S D=8.44)$ in school settings. Most $(77.8 \%)$ were the only school social workers in their buildings. Many $(35.2 \%)$ served only one building; $18.5 \%$ served two buildings, and $42 \%$ served three or more buildings.

Many practice with more than one age level. Respondents indicated they serve the following levels: 


\begin{tabular}{|ll|}
\hline $33.3 \%$ & Preschool \\
$70.4 \%$ & Elementary \\
$42.6 \%$ & Middle School \\
$33.3 \%$ & High School \\
$20.4 \%$ & Alternative Schools \\
\hline
\end{tabular}

Respondents indicated that their funding comes from a variety of sources, with $64.8 \%$ receiving some funding from special education, $59.3 \%$ from general education funds, and $18.5 \%$ receiving grant funds. On average, school social workers indicted that their positions are funded by $1.5(\mathrm{SD}=.61)$ different funding sources.

\section{Findings}

It was hypothesized that there would be differences in the way school social workers practiced group work depending on the age of the students served and on the way the positions were funded. Few differences were found, and these differences are predictable.

\section{Funding Source}

Analysis of Variance was used to determine the difference between mean scores on a number of variables based on the independent variable of funding source. It was hypothesized that school social workers who are funded by general education funds would be asked to work with larger numbers of students and would, therefore, be more likely to use groups than those who are funded by 
special education. This was not the case. Only one area showed significant differences.

School social workers funded by special education funds are significantly more likely $(p=0.002)$ to work with special education students than those funded by grant, general education, or a combination. Social workers funded by special education funds indicated an average of $71 \%(S D=34.4)$ of the students they work with have an IEP, compared with $32.3 \%(S D=26.2)$ with an IEP for school social workers funded by general education funds, $4.8 \%(S D=4.6)$ for those funded by grants, and $43.5 \%$ (SD=30.3) for those receiving funds from a combination of sources.

Table 2

Percentage of Special Education Students in Groups Analyzed by Funding Source

\begin{tabular}{|c|r|r|l|r|r|}
\hline & N & \multicolumn{1}{|c|}{ Mean } & \multicolumn{1}{c|}{ SD } & F & Sig \\
\hline Special Ed & 14 & 71.00 & 34.39 & & \\
\hline General Ed & 13 & 32.33 & 26.18 & & \\
\hline Combination & 23 & 43.52 & 30.32 & & \\
\hline Grant & 2 & 4.75 & 4.60 & & \\
\hline Total & 52 & 47.28 & & & \\
\hline & & & & 5.78 & .002 \\
\hline
\end{tabular}

\section{Age Level}

Analyses of Variance were used to determine if there were differences in responses by age level of students served. Few differences were identified based on age. School social workers who serve more than one age level conduct significantly fewer groups $(p=0.016)$ per week (mean=3.47, $S D=3.83)$ than social workers who serve only elementary (mean=7.9, $S D=6.2$ ). While social workers 
who serve secondary schools conduct fewer groups per week (mean=4.25, $S D=3.74)$ than those who serve elementary students, the difference between them was not statistically significant, using a Tukey post hoc analysis, perhaps because of the large standard deviation in the mean number of groups at the elementary level.

Table 3

Number of Groups Per Week Analyzed by Grade Level

\begin{tabular}{|c|r|r|l|l|l|}
\hline & N & Mean & SD & F & Sig \\
\hline & & & & & \\
\hline Primary & 22 & 7.898 & 6.20 & & \\
\hline Secondary & 13 & 4.250 & 3.74 & & \\
\hline Multiple & 18 & 3.472 & 3.83 & & \\
\hline Total & 53 & 5.500 & 5.27 & & \\
\hline & & & & 4.510 & .016 \\
\hline
\end{tabular}

School social workers who serve more than one level spend significantly $(p=0.037)$ less time per week conducting groups (mean=105 minutes/week, $\mathrm{SD}=67)$ ) than social workers in primary settings (mean=248 minutes per week, SD 266) or secondary settings (mean $=249, S D=198$ ). This may be because school social workers serving a combination of schools are in more buildings and have less time to conduct groups.

Table 4

Total Minutes Conducting Groups per Week Analyzed by Age Level

\begin{tabular}{|c|r|r|l|l|l|}
\hline & N & Mean & \multicolumn{1}{c|}{ SD } & F & Sig \\
\hline & & & & & \\
\hline primary & 22 & 247.95 & 265.75 & & \\
\hline secondary & 12 & 249.17 & 198.07 & & \\
\hline combination & 18 & 105.28 & 66.96 & & \\
\hline Total & 52 & 198.85 & 193.82 & & \\
\hline
\end{tabular}




\begin{tabular}{|l|l|l|l|l|l|}
\hline & & & & 3.526 & .037 \\
\hline
\end{tabular}

While respondents serving primary schools spent almost exactly the same amount of time conducting groups as those serving secondary schools, those at the primary level conducted almost twice as many groups $(7.90 /$ week, $S D=6.20)$ as secondary school social workers $(4.25, \mathrm{SD}=3.74)$. It appears that social workers at the secondary level are conducting longer groups, most likely for a class period (mean=57.1 minutes, $S D=27.9$ ), while elementary social workers' groups average 32.3 minutes $(S D=17.9)$ in length.

Table 5

Number of Minutes of Each Group Analyzed by Age Level

\begin{tabular}{|c|r|r|l|l|l|}
\hline & N & Mean & SD & F & Sig \\
\hline & & & & & \\
\hline primary & 22 & 32.27 & 17.9 & & \\
\hline secondary & 12 & 57.10 & 27.7 & & \\
\hline combination & 17 & 46.93 & 36.4 & & \\
\hline Total & 51 & 43.00 & 28.8 & & .041 \\
\hline & & & & 3.417 & \\
\hline
\end{tabular}

Type of Group

It was hypothesized that social workers in different settings or with different funding sources would address different issues in their groups. Chi square analysis was used to determine if there were any significant differences on a number of variables using the dependent variables of funding source and age level. The only significant difference identified was that school social workers at the primary level are significantly more likely $(p=0.015)$ to be conducting family 
change groups (54\%) than those at the secondary level $(8 \%)$ or those serving more than one age level (28\%).

With the exception of the areas mentioned above, school social workers at all age levels and with various types of funding appear to be conducting similar types of groups and addressing similar issues. Because of this, the remaining results of the survey will not be reported by age level or funding source.

With the exception of family change groups, social workers were conducting many different kinds of groups in all settings. It appears by the numbers of kinds of groups reported that the workers are conducting groups that address multiple issues. Respondents were presented a list of kinds of groups and asked to indicate which ones they had led in the previous year. Responses are indicated in Table 6.

Table 6 Kinds of Groups Conducted

87.0\% Social skills

59.3\% Peer Difficulties

$55.6 \%$ Behavior management

$48.1 \%$ Self esteem

46.3\% Affect and Emotions

$40.7 \%$ Bullying or aggression

$37.0 \%$ Family Difficulties or Problems

$35.2 \%$ Family change

$35.2 \%$ Grief and loss

$27.8 \%$ ADHD

25.9\% Substance abuse

$25.9 \%$ Anxiety Reduction
24.1\% Academic achievement 20.4\% Assertiveness

18.5\% Discipline

9.3\% Leadership

9.3\% Disabilities

7.4\% Diversity, Race, or Ethnicity

5.6\% Support

$3.7 \%$ Eating problems/disorders

$3.7 \%$ Student Council

$3.7 \%$ Victimization

$0 \%$ Immigration Issues

$0 \% \mathrm{GLBT}$ issues

Respondents had an opportunity to include other kinds of groups that they are leading that were not provided in the survey. The following kinds of groups 
were added: hygiene, adjustment to middle school, anger management, suicide prevention, conflict resolution, problem solving, and parents' groups.

\section{Scope of Group Work in Schools}

On average, school social workers saw a total of $79.04(S D=174.31$, range $0-1120)$ students in groups during the last school year, The large standard deviation reflects the wide variance of the number of students social workers reported seeing in groups. One reported seeing 1120 students in groups the previous year; eight indicated that they saw 100 or more students in groups. Workers reported conducting an average of $5.45(S D=5.23$, range $0-25)$ groups each week. They spent $197.0(\mathrm{SD}=192.43$, range 0-720) minutes conducting groups weekly, and $38.38(\mathrm{SD}=54.52$, range $0-360)$ minutes recording what took place in those groups. While they spent $65.04(\mathrm{SD}=61.07$, range $0-60)$ minutes planning all their groups, they spent an average of $26.88(S D=17.77$, range 0-60) minutes planning each group. This discrepancy may be because they lead several groups using the same or similar plans, thus reducing their total planning time.

Clearly group work practices vary widely from worker to worker. There was great variation in the social workers' responses regarding the number of groups they facilitate and the amount of time they spend facilitating, planning, and recording groups. This resulted in considerable negative skew in the data, with high numbers disproportionately represented. For example, the mean 
number of minutes workers spend conducting groups each week was 197, just over 3 hours per week. But 8 workers reported spending more than 6 hours per week facilitating groups, leading to a large standard deviation of 192 minutes. Similarly, respondents had a wide range in the time they spend planning and recording groups each week.

Group size varied widely from a minimum of two students to a maximum of 80. On average groups had $6.2(\mathrm{SD}=3.34)$ members, which was slightly larger than the average ideal size school social workers chose as their preferred size, $5.56(\mathrm{SD}=1.85)$. The average number of sessions school social workers conduct groups was $16.56(S D=13.83)$. This number was influenced by several social workers who reported conducting groups for a semester or the entire school year. The mode, or most frequently mentioned lengths were 6 weeks and 8 weeks, both of which were identified by 7 respondents. It is clear, however, that group length varies widely. The most common frequency of groups is to meet weekly, as reported by $75.9 \%$ of respondents.

\section{Structure of School-Based Social Work Groups}

When asked about the amount of structure they prefer in their groups, respondents indicated that they like some structure, but not too much, rating their preference at $6.5(\mathrm{SD}=1.35)$ on a 10-point scale, with 10 representing a preference for high structure. They identified their leadership styles as just below the midpoint $(M=4.51, S D=1.71)$ of a 10-point scale ranging from directive (1) to 
non-directive (10). Although one respondent wrote in that leadership style depends on age of the students, there was no statistically identifiable difference in responses based on student age. Group rules are usually developed jointly between leaders and members $(79.6 \%)$, but $14.8 \%$ of the social workers indicate that they develop rules without consulting members.

One-third (33.3\%) of respondents like a mixture of program activities and discussion, while $37 \%$ prefer using all program activities and planned curricula, and $28 \%$ prefer to rely only on group discussion. Half $(50 \%)$ of the social workers make decisions themselves as to what activities groups will do during sessions, while the other half (50\%) share decision making on activities with members.

The school social workers sampled use several strategies for developing program activities for their groups. On the continuum from preferring to develop their own curricula (1) to preferring curricula developed by others (10), respondents came down firmly in the middle, with a mean score of 5.31 $(S D=1.79)$, leaning only slightly toward a preference for others' curricula. When asked which they were more likely to actually do, the rating was slightly lower $(M=4.76, S D=1.75)$. What this apparently means is that social workers would like to use curricula developed by others, but slightly more often end up developing their own materials instead.

When asked to name their favorite "resources, program, or tools," they listed a wide range of programs, curricula, art activities, toys, games, books, and team building activities. In fact, the 53 respondents named 51 different programs. 
Only two programs were named more than once; the Talking, Feeling, and Doing Game (Gardner, 1998) and Second Step (Seattle Institute for Child Advocacy; 1997) were both listed three times. Of the respondents, 26 listed published curricula; 8 indicated activities they develop themselves using toys, games, and art; and 8 listed both published programs and made-up activities.

Most school social workers close their groups to new members, with $63 \%$ conducting closed groups and $33.3 \%$ indicating that their groups are usually open. Finding adequate space to conduct groups is a challenge for some, with $40.7 \%$ indicating that they do not have adequate space to conduct groups.

\section{Theoretical Orientation}

Cognitive/behavioral therapies dominated the theoretical orientations selected by the school social work respondents, as noted in Table 7.

Table 7

Theoretical Orientations

63.0\% Cognitive/behavioral $57.4 \%$ Brief, Short Term $57.4 \%$ Solution Focused $57.4 \%$ Strengths Perspective $55.6 \%$ Behavior modification 46.3\% Problem Solving $33.3 \%$ Crisis Intervention 33.3\% Family Systems 33.3\% Task Centered
$31.5 \%$ Person Centered 27.8\% Reality Centered 24.1\% Developmental Theories

18.5\% Small Group Theory 13.0\% Ethnic sensitive $11.1 \%$ Eco systems $11.1 \%$ Psychodynamic $5.6 \%$ Feminist

Not only was a general cognitive/behavioral category the most frequently identified theoretical orientation, the other four interventions that were used by 
more than half of he school social workers could arguably be considered subsets or overlaps of the cognitive/behavioral category. Given the educational focus of schools, it is not surprising that these theory bases were the most commonly used. School social workers are combining a number of theoretical frameworks in their group work. The average total number of theories used was $5.83(\mathrm{SD}=2.85)$. It is interesting to note that relatively low use of eco-systems theory (by $11 \%$ of the respondents), often used as a conceptual framework for school social work books (see, for example, Allen-Meares, Washington, \& Welsh, 2000; Germain, 2002) and the low rate of use of small group theory (by 18.5\%) as a conceptual base for school-based group work.

\section{Group Dynamics}

One of the research questions was whether school social workers adapt programs to integrate their knowledge of stages of group development when it is not present in the original curriculum. In an effort to determine the degree to which school social workers integrate their knowledge of group stages into their practice, respondents were asked how frequently they adapt the curricula developed by others to accommodate stages of group development. On a 10pont scale from "infrequently" (1) to "frequently (10), the mean rating was 7.31 $(S D=2.12)$. The mode or most often picked rating was 8 . In other words, school social workers adapt group work curricula regularly to fit it with group stages. 
Respondents' descriptions of a typical group indicated that they begin their groups with non-threatening activities such as introductions, discussions of group purpose, goal setting, and rules. A typical description of a beginning group was "Non-threatening get-to-know activity. Ice breaker that leads to discussion about goals of group. Finishing with beginning development of rules." One respondent who did not use process-oriented activities in the beginning identified it as "not a typical group" because he or she was working with preschoolers and using "structure based on lessons." In other words, this school social worker indicated that the use of a "canned" set of lessons did not fit with the inclusion of group dynamics. Respondents' description of a typical middle session usually ( $66 \%$ of the respondents) included mention of a group process in some form, referring to group goals, emotional ties, trust, or interpersonal interaction. Typical of middlestage descriptions were "testing of group rules, confrontation of member behavior," "using an activity to discuss group topic (typically problem-solving)," and "perhaps doing an intervention between group members (either done by facilitator or other group members)." One-third of the respondents did not identify dynamics in the middle stage. Typical responses that avoided mention of process were "share information" and "focus on topic and review of previous week's lesson." As with the beginning phase, virtually all respondents report an awareness of group process issues at the ending stage, indicating that they plan a celebration, review accomplishments of goals, plan for the future, or discuss the termination. 
Respondents were asked how frequently they adapt curricula to address group dynamics, "for example, by adding an activity to encourage quiet member to join in or to discourage a talkative member from talking so much" on a 10-point continuum from "infrequently" (1) to "frequently" (10). The mean score was 6.21 $(S D=2.52)$. The mode was 7. It appears that school social workers are adapting to meet the needs of members and to foster positive dynamics in their groups, but they appear to be doing slightly less to encourage positive dynamics than they adapt to fit with the stage development of their groups. The age level of students being served had no significant effect on any of the variables measuring group dynamics.

In an effort to determine how school social workers develop positive interaction among members, respondents were asked an open question about how they encourage group members to be kind and helpful to each other. By far the greatest response was "rules," followed by "modeling" of kind or supportive behavior. Other strategies listed were gentle reminders, individual goals, positive reinforcement, and peer pressure. It was clear that those who responded had thought carefully about this, and had strategies to encourage student cooperation, team building, and empathy. While nearly all (94.4\%) of the respondents reported using cooperative activities in their groups, only $37.0 \%$ indicated that they use competitive activities.

\section{Discussion}


This study is limited by the small sample size and low response rate, so conclusions from the results must be drawn cautiously. Nevertheless, it provides an exploratory analysis of the group work practice being conducted by school social workers. The results of this study indicate that school social workers' use of group work varies greatly. Some are conducting very few groups while others use group work extensively, seeing many students and spending much of their time facilitating groups. Respondents are conducting a wide range of groups, most commonly addressing social skills, peer difficulties, behavior, self-esteem, emotional development, bullying, aggression, family difficulties, and grief and loss, with students from preschool to high school. These groups are not limited to students with identified disabilities or special needs. School social workers are leading, on average, 5.5 groups per week with 6.2 members per group. Most groups are between 6 and 8 sessions long, although there is great variation in group length. While there were few notable differences between the groups conducted at the secondary level and elementary level, groups at the secondary level meet for longer sessions. Family change groups are much more common at the elementary level than at the secondary level.

Respondents reported heavy reliance on cognitive behavioral theory in framing their work with students in groups. In fact, the top six theoretical frameworks listed could be considered cognitive or behavioral in nature. This is perhaps because of the educational nature of schools as an institution of thinking, teaching, and learning. 
School social workers are using activities in their groups, although they clearly complement these activities with a great deal of verbal discussion. They use of toys, games, books, art, and published curricula. They do not hesitate to adapt programs to meet the needs of their students and to foster the development of group processes. School social workers are using many of the principles of small group theory, including use of group dynamics, adapting curricula to fit stages of development. They encourage cooperation and mutual helping among members. It appears that, for the most part, respondents to this survey are not practicing "casework in a group" (Kurland \& Salmon, 1992), but rather are going beyond the simple use of activities and working to nurture mutual aid and the supportive interpersonal interactions that are the basis for the success of groups (Northern \& Kurland, 2001). Yet few school social workers state that they are actively using small group theory to guide their group interventions. This paradox between the apparent use of group dynamics without identifying small group theory as a theoretical framework raises interesting questions about the way school social workers frame their practices.

\section{Conclusion}

Group work is clearly being used extensively by school social workers in an effort to help students overcome common barriers to achieving educational success. Group work has the advantage of serving several students simultaneously, developing social skills, providing a forum for students to give aid 
to others and accept help, realizing that others share their challenges, collaborating, cooperating, and sharing. While respondents did not identify that they are using small group theory as a conceptual framework, they are clearly incorporating activities that foster group development and encourage positive group dynamics to help students cooperate and help each other. Perhaps this group work practice could be further enhanced by a more systematic use of group theory with its attention to the development of group process and mutual aid to accomplish individual and group goals. 


\section{References}

Allen-Meares, P., Washington, R.O., \& Welsh, B.L. (2000). Social work services in schools. Boston: Allyn \& Bacon.

Bacha, T., Pomeroy, E.C., \& Gilbert, D. (1999). A psychoeducational group intervention for HIV-positive children: A pilot study. Health and Social Work, 24(4), 303-306.

Beane, A.L. (1999). Bully free classroom. Minneapolis: Free Spirit Publishing.

Becker, M.G., \& Barth, R.P. (2000). Power through choices: The development of a sexuality education curriculum for youths in out-of-home care. Child Welfare, 79(3), 269-282.

Browning, P., \& Nave, G. (1993). Teaching social problem solving to learners with mild disabilities. Education and Training in Mental Retardation, 28(4), 309-317.

Collins, L. (1998). How do you spell hippopotamus? The use of group work in after-school tutoring programs. Social Work with Groups, 21(1/2): 61-75.

DeMar, J. (1997). A school-based group intervention to strengthen personal and social competencies in latency-age children. Social Work in Education, 19(4), 219-230.

Dygdon, J.A. (1993). The Culture and lifestyle-appropriate social skills intervention curriculum (CLASSIC): A program for socially valid social skills training. Brandon, VT: Clinical Psychology Publishing Company, Inc.

Eggert, L.L. (1994). Anger management for youth : Stemming aggression and violence. Bloomington, IN: National Educational Service.

Fatout, M.F. (1995). Using limits and structures for empowerment of children in groups. Social Work with Groups, 17(4), 55-69.

Forgan, J.W., \& Jones, C.D. (2002). How experiential adventure activities can improve students' social skills. Teaching Exceptional Children, 34 (3), 5258.

Frey, K., \& Sylvester, L. (1997). Research on the Second Step Program: Do student behaviors and attitudes improve? What do teachers think about the program? Seattle: Committee for Children. 
Garland, J., Jones, H., \& Kolodny, R. (1965). A model for stages of development in social work groups, in S. Bernstein (Ed.), Explorations in Group Work (pp. 12-53). Boston: Boston University Press.

Gardner, R.A. (1998). The talking, feeling, and doing game: A psychotherapeutic game for children. Cresskill, NJ: Creative Therapeutics.

Germain, C. (2002). An ecological perspective on social work in the schools. In R. Constable, S. McDonald \& J.P. Flynn (Eds.) School social work: Practice, policy, and research perspectives ( $5^{\text {th }}$ ed.) (pp. 25-35). Chicago: Lyceum Press.

Garrity, C., Jens, K., Porter, W., Sager, N., Short-Camilli, C. (2000). Bullyproofing your school. ( $2^{\text {nd }}$ ed.). Longmont, CO: Sopris West.

Garvin, C. (1985). Group process: Usage and uses in social work practice. In M. Sundell, P. Glasser, R. Sari, \& R. Vinter (Eds.), Individual Change through Small Groups (pp. 203-225). New York: The Free Press.

Hanna, J.C., \& Maddalena, G. (1994). Respect, reflect, resolve: Ten antiviolence lessons for use in middle and high school. Washington, DC: Phi Alpha Delta Law Fraternity International

Goldstein, A.P., \& McGinnis, E. (1997). Skillstreaming the adolescent: New strategies and perspectives for teaching prosocial skills. $\left(2^{\text {nd }} \mathrm{ed}.\right)$. Champaign, IL: Research Press.

Kurland, R., \& Salmon, R. (1978). Planning: A neglected component of group development. Social Work with Groups, 1(2), 173-179.

Kurland, R., \& Salmon, R. (1992). Group work vs. casework in a group: Principles and implications for teaching and practice. Social Work with Groups, 15(4), 3-14.

Larson, J.D. (1992). Anger and aggression management techniques through the "Think First" curriculum. Journal of Offender Rehabilitation, 18(1-2), 101117.

LeCroy, C.W. (2002) Social skills groups in schools. In R. Constable, S. MacDonald \& J.P. Flynn (Eds.). School social work: Practice, policy, and research perspectives $\left(5^{\text {th }}\right.$ ed.). (pp. 404-421). Chicago: Lyceum Press. 
Lochman, J.E., Dunn,S.E., \& Klimes-Dougan, B. (1993). An intervention and consultation model from a social cognitive perspective: A description of the anger coping program. School Psychology Review, 22(3), 458-471. (order to check article 7.7.03)

McGinnis, E., Goldstein, A. P., Sprafkin, R.P., \& Gershaw, N.J. (1984). Skillstreaming the elementary school child: A guide for teaching prosocial skills. Champaign, IL: Research Press.

Malekoff, A., \& Laser, M. (1999). Addressing difference in group work with children and young adolescents. Social Work with Groups, 21(4): 23-34.

Martin, H. (1994). A self-control curriculum for troubled youngsters. Journal of Emotional and-Behavioral Problems, 3(1), 40-46.

Mayerson, C.R. (2000). An exploratory study of group-as-a-whole dynamics in children's group therapy. Journal of Child and Adolescent Group Therapy, 10(3), 131-150.

Mayadas, N., \& Glasser, P. (1981). Termination: A neglected aspect of social group work. Social Work with Groups, 4(1), 193-203.

Middleman, R.R., \& Wood, G.G. (1990). Skills for direct practice in social work. New York: Columbia University Press.

Moroz, K.J. (1996). Kids speak out on adoption: a multiage book-writing group for adopted children with special needs. Child Welfare, 75(3), 235-251.

Nichols, P. (1997). Problem solving for personal power. Reclaiming Children and Youth: Journal of Emotional and Behavioral Problems. 6(2), 75-81.

Northern, H., \& Kurland, R. (2001). Social work with groups ( $3^{\text {rd }}$ ed.). New York: Columbia University Press.

O'Neal, G.S. (1997). Focusing on strengths in a special education class: a primary prevention approach. Social Work in Education, 19(4), 279-284.

Pawlak, E.J., Wozniak, D., \& McGowen, M. (2002). Perspectives on groups for school social workers. In R. Constable, S. MacDonald \& J.P. Flynn (Eds.). School social work: Practice, policy, and research perspectives ( $5^{\text {th }}$ ed.). (pp. 404-421). Chicago: Lyceum Press.

Rockwell, S. (1993). Tough to reach, Tough to teach: Students with behavior problems. Reston, VA: Council for Exceptional Children. 
Rose, S.D., \& Edleson, J. (1987). Working With children and adolescents in groups. San Francisco: Jossey-Bass.

Schiller, L.Y. (1995). Stages of development in women's groups: A relational model. In R. Kurland \& R. Salmon (Eds.) Group work practice in a troubled society: Problems and opportunities (pp. 117-138). Binghamton NY: Haworth Press.

Seattle Institute for Child Advocacy. (1997). Second step: a violenceprevention curriculum: Preschool-kindergarten, ages 4-6. Seattle, WA: Committee for Children.

Springer, D.W., Lynch, C., \& Rubin, A. (2000). Effects of a solution-focused mutual aid group for Hispanic children of incarcerated parents. Child and Adolescent Social Work Journal, 17(6): 431-442.

Sullivan, K. (2000). The anti-bullying handbook. Auckland, N.Z.: Oxford University Press.

Sunburst. (2000). Help your child make good decisions. Pleasantville, NY: Sunbust Technology.

Taylor, G.R. (1997). Curriculum strategies for teaching social skills to the disabled: Dealing with inappropriate behaviors. Springfield, IL: Charles C. Thomas Publisher, Ltd.

Toseland, R.W., \& Rivas, R.F. (2001). An introduction to group work practice. $\left(4^{\text {th }}\right.$ ed.). Boston: Allyn \& Bacon.

Webster-Stratton, C., Reid, J. \& Hammond, M. (2001). Social skills and problemsolving training for children with early-onset conduct problems: Who benefits? Journal of Child Psychology and Psychiatry and Allied Disciplines, 42(7), 943-952.

Witte, S.S., \& deRidder, N.F. (1999). Positive feelings: Group support for children of HIV-infected mothers. Child and Adolescent Social Work Journal, 16(1), 5-21.

Wohl, B.J. (2000). The power of group work with youth: Creating activists of the future. Social Work with Groups, 22(4), 3-13.

Woody, D. (2001). A comprehensive school-based conflict-resolution model. Children and Schools, 23(2), 115-124. 
Seattle Institute for Child Advocacy. Second step: a violence-prevention curriculum: preschool-kindergarten, ages 4-6. Seattle, WA: Committee for Children, 1997. 